\title{
Gene silencing by RNA interference in Sarcoptes scabiei: a molecular tool to identify novel therapeutic targets
}

\author{
Deepani D. Fernando 1,2,4, Edward J. Marr ${ }^{3}$, Martha Zakrzewski', Simone L. Reynolds', Stewart T. G. Burgess ${ }^{3}$
} and Katja Fischer ${ }^{1 *}$

\begin{abstract}
Background: Scabies is one of the most common and widespread parasitic skin infections globally, affecting a large range of mammals including humans, yet the molecular biology of Sarcoptes scabiei is astonishingly understudied. Research has been hampered primarily due to the difficulty of sampling or culturing these obligatory parasitic mites. A further and major impediment to identify and functionally analyse potential therapeutic targets from the recently emerging molecular databases is the lack of appropriate molecular tools.

Methods: We performed standard BLAST based searches of the existing S. scabiei genome databases using sequences of genes described to be involved in RNA interference in Drosophila and the mite model organism Tetranychus urticae. Experimenting with the S. scabiei mu-class glutathione S-transferase (SSGST-mu1) as a candidate gene we explored the feasibility of gene knockdown in S. scabiei by double-stranded RNA-interference (dsRNAi).

Results: We provide here an analysis of the existing S. scabiei draft genomes, confirming the presence of a double stranded RNA (dsRNA) - mediated silencing machinery. We report for the first time experimental gene silencing by RNA interference (RNAi) in S. scabiei. Non-invasive immersion of S. scabiei in dsRNA encoding an S. scabiei glutathione S-transferase mu-class 1 enzyme (SSGST-mu1) resulted in a 35\% reduction in the transcription of the target gene compared to controls.

Conclusions: A series of experiments identified the optimal conditions allowing systemic experimental RNAi without detrimental side effects on mite viability. This technique can now be used to address the key questions on the fundamental aspects of mite biology and pathogenesis, and to assess the potential therapeutic benefits of silencing S. scabiei target genes.
\end{abstract}

Keywords: Scabies mites, Sarcoptes scabiei, RNA interference, Gene knockdown, Glutathione S-transferase

\section{Background}

Scabies shows many typical features of a truly neglected tropical disease $[1,2]$. It is a skin disease that affects worldwide, primarily economically disadvantaged populations [3-6]. It is common in the tropics and here the initial epidermal skin infections with parasitic mites often escalate into complex secondary infections with mite-associated bacterial pathogens, potentially causing serious subsequent sequelae. Burrowing mites and host

\footnotetext{
* Correspondence: Katja.Fischer@qimrberghofer.edu.au

'QIMR Berghofer Medical Research Institute, Infectious Diseases Department,

300 Herston Road, Herston, Brisbane 4006, Australia

Full list of author information is available at the end of the article
}

scratching responses cause disruption of the skin barrier, thereby providing an entry point for bacteria, which can become invasive, or cause post-infection complications (e.g. post-streptococcal glomerulonephritis and rheumatic heart disease) [7]. The entire scabies mite life-cycle is 'obligatory parasitic' [8] as scabies mites are thought to be extremely vulnerable to water loss [9-11]. Environmental reservoirs have not been reported, except for a small proportion of adult mites opportunistically surviving on fomites for a few days [12-14] if under optimal conditions, i.e. high relative humidity and moderate temperatures. Hence treatment of infected hosts is the most direct way to effectively combat the disease. There is no 
vaccine against scabies, and it is doubtful whether vaccine development is feasible or affordable [15]. Only a few broad spectrum anti-parasitic drugs are currently in use to treat scabies $[16,17]$, but these often fail to control the disease because of their limited ovicidal activity and their short half-lives $[18,19]$. This dictates multiple treatments and combining topical and systemic drugs, which causes considerable management issues [19]. In addition the first evidence of emerging resistance in scabies mites against the most commonly used drugs permethrin [20] and ivermectin [21, 22] have been reported. Importantly, no sensitive and simple molecular diagnostic tools are currently available and this is the main reason for the worldwide deficit in scabies surveillance, as summarised recently [3]. The fact that scabies is not a reportable disease in many countries further impedes the accurate accounting of scabies prevalence. As a consequence the public health burden due to scabies and associated secondary infections is under-recognised worldwide and accordingly, funding for health services to control scabies or for research to gain further knowledge about the disease is extremely limited. As a result, scabies (and mange) remains a small, understudied research field.

Aside from the challenges presented due to a lack in recognition from a funding perspective, scabies is also a difficult disease to study practically. S. scabiei resides within the epidermis throughout its entire life-cycle [8] and its water balance appears to be highly adapted to the conditions within the protective matrix of the stratum corneum [10]. Establishing a continuous in vitro culture would require precise mimicking of the epidermal conditions; this has only been accomplished to a limited extend [23]. Currently most molecular and biochemical research of the parasite still relies entirely on sampling of mites from the living host. However, most human as well as animal hosts, if not treated, develop chronic but selflimiting scabies infestations, harbouring relatively few parasites on their bodies (up to 20 in humans [24]). These mites are of microscopic size $(<400 \mu \mathrm{m}$ in length), and high numbers of parasites are needed for research applications. As a consequence most scabies infections are not suitable for laboratory based parasite studies. For all these reasons mite molecular biology and biochemical research of S. scabiei remains a largely unexplored field and has lagged behind within the field of acarology. Consequently, until very recently, few molecular data existed and none of the molecular tools already established in other parasite research fields were available.

To overcome the significant lack of molecular data on scabies a few research groups have attempted to deploy the only substantial parasite material sources available, which are animal and human cases of crusted or Norwegian scabies. Formation of hyperkeratotic skin crusts is a very rare and extreme form of scabies occurring predominantly in immune-compromised individuals (reviewed in [25]). In this condition thousands of mites are contained per gram of skin crust. Crusted scabies is a rare but terrible state of this disease, requiring intensive care and long-term treatment. These rare cases have the potential to provide the only substantial resource of parasites for molecular research, for example samples from two such patients facilitated the generation of the first S. scabiei var. hominis draft genome database [26]. Furthermore, an in vivo porcine model has been established recently, where localised crust formation can be enforced by the administration of immune suppressing steroids [27]. The development of this model system has allowed for the commencement of a genome [26], transcriptome and proteome project of $S$. scabiei var. suis mites [manuscript in progress]. Draft genome and proteome databases of S. scabiei var. canis have also been established [28, 29]. The generation of these molecular databases will allow us to understand fundamental aspects of mite biology and pathogenesis in order to develop novel control strategies.

In the advent of the establishment of mite multi-omics it is compulsory to develop molecular tools and techniques that allow experimentation, analysis and exploration of the molecular information gained. RNA interference (RNAi) is a reverse genetic tool displaying promising analytical potential to explore gene function [30]. This technology has enabled the analysis of gene function in numerous organisms and could facilitate the systematic selection of potential chemotherapeutic target molecules from the newly established $S$. scabiei molecular data sets. Similar work with other arthropods is underway and RNAi has been previously applied for ticks [31], flies and parasitic copepods (reviewed in [30]). RNAi silencing has been demonstrated in a few mites, including the pest mites Varroa destructor (honey bee mite) [32, 33], Tetranychus urticae (two-spotted spider mite) [34] and Dermanysus gallinae (poultry red mite) [35] and also in Metaseiulus occidentalis [36], an agriculturally important biological control agent of plantfeeding pest mites. More recently RNAi has also been tested in Sarcoptiformes mites including the notorious house dust mite Dermatophagoides pteronyssinus [37] and the sheep scab mite, Psoroptes ovis (E. J. Marr personal communication). Glutathione S-transferase mu1 (GST-mu1) has been the gene target of choice for most studies aiming to establish RNAi in mites. GSTs play critical roles in detoxification and have been shown to be involved in the development of acaricide resistance [38-40]. RNAi can be achieved by the introduction of either double-stranded RNA (dsRNA) or small interfering RNA (siRNA) into an organism, provided the organism possesses the principal effectors of the RNAi pathway. 
RNAi is thought to have evolved as a defence against viruses and is indeed a highly conserved mechanism of genetic regulation present in many eukaryotes (reviewed in [30]). When introduced into a target cell, ds/siRNA is processed and incorporated into the RNA-induced silencing complex (RISC), which leads to the specific cleavage of gene-specific messenger RNA (mRNA) with complementary sequence homology to the ds/siRNA trigger [41]. The phenotype arising from the reduction in gene specific transcription levels caused by RNAi can indicate the function(s) of the protein encoded by the target gene and thereby may suggest its importance to the host organism, as recently summarised for the study of tick physiology [31]. In organisms like S. scabiei, for which annotated genomic information does not yet exist, and for which transfection has not been established, RNAi could be a useful technology to inform on the potential of candidate genes as novel intervention targets. To date there has been no report of RNAi being trialled in scabies mites, possibly due to the above mentioned limitations of sampling, their miniscule size and the difficulty in maintaining them in vitro. We have analysed the recently generated draft genome databases of S. scabiei varieties from canine, porcine and human hosts for the presence of the RNAi machinery and report here the basic and typical elements of an RNAi pathway in S. scabiei. We also developed a non-invasive RNAi methodology specific for S. scabiei and demonstrate the successful experimental gene-silencing of SsGST-mu1 in $S$. scabiei var. suis following immersion in complementary dsRNA.

\section{Methods}

\section{Reference sequences for screening RNAi pathway} components in Sarcoptes scabiei genomic databases

The reference sequences of proteins involved in small RNA-mediated silencing in Tetranychus urticae were obtained from Grbic et al. [42] and in Drosophila melanogaster from NCBI protein and Swissprot databases. The reference identification numbers used are listed in Table 1.

\section{Interrogation of Sarcoptes scabiei genome databases}

Sarcoptes scabiei draft reference genome databases for $S$. scabiei var. canis [28], S. scabiei var. suis [26] and S. scabiei var. hominis [26] were analysed using BLAST software [43] through the National Center for Biotechnology Information (NCBI). To identify molecules involved in the RNAi pathway in S. scabiei a standard protein-protein BLAST (BLASTp) search against the predicted protein sequences of the S. scabiei var. canis draft genome was performed. To screen the S. scabiei var. hominis and $S$. scabiei var. suis databases the BLAST-like alignment tool 'BLAT' was used, aligning protein sequences vs translated nucleotide database [44]. Subsequently, genes were
Table 1 Reference genes used to search S. scabiei databases

\begin{tabular}{ll}
\hline Gene family (Organism) & Gene ID \\
\hline Dicer (T. urticae) & tetur07g00990.1.1; tetur19g00520.1.1 \\
Argonaute (T. urticae) & tetur02g10560.1.1; tetur02g10570.1.1; \\
& tetur02g10580.1.1; tetur04g01190.1.1; \\
& tetur09g00620.1.1; tetur09g03140.1.1; \\
& tetur20g02910.1.1 \\
Piwi/Aub/Ago3 (T. urticae) & tetur06g03300.1.1; tetur06g05570.1.1; \\
& tetur17g03380.1.1; tetur06g05600.1.1; \\
& tetur28g00450.1.1 \\
Pasha (T. urticae) & tetur36g00220.1.1; tetur36g00250.1.1 \\
Drosha (T. urticae) & tetur12g00910.1.1 \\
GW182 (T. urticae) & tetur05g07970.1.1; tetur09g00260.1.1 \\
VIG (T. urticae) & tetur22g01310.1.1 \\
Loquacious(T. urticae) & tetur13g00410.1.1; tetur13g00430.1.1 \\
Exportin-5 (T. urticae) & tetur02g00500.1.1; tetur02g00520.1.1 \\
RdRP (T. urticae) & tetur02g08750.1.1; tetur02g08780.1.1; \\
Dicer (Drosophila) & tetur02g08810.1.1; tetur02g08820.1.1 \\
R2D2 (Drosophila) & XP_017874916.1 \\
Argonaute (Drosophila) & NP_001285720.1 \\
GW182 (Drosophila) & XP_016037320.1; XP_015024007.1 \\
Piwi (Drosophila) & XP_015024007.1; XP_016037320.1 \\
Exportin (Drosophila) & XP_002051133.2; XP_015033122.1; \\
dsRNA binding domain, & XP_002003896.1 \\
(Drosophila) & XP_017154884.1; XP_002058203.1 \\
RNase III domain (Drosophila) & XP_002016656.1; XP_015022070.1 \\
C3PO (Tribolum castaneum) & XP_002016656.1 \\
\hline & ABX72055 \\
\hline
\end{tabular}

predicted in the human and pig mite genomes using the software 'MAKER' v2.31.9 [45, 46].

\section{Sarcoptes scabiei mites}

Sarcoptes scabiei var. suis mites were harvested from the previously established porcine animal model [27]. Skin crusts were removed from the host and adult female mites were isolated within $3 \mathrm{~h}$ of harvesting.

\section{Double stranded RNA (dsRNA) preparation}

The partial sequence of the target gene S. scabiei glutathione S-transferase mu class 1 (SsGST-mu1) (GenBank GQ214688.1) consisting of $335 \mathrm{bp}$ and the negative control gene LacZ of Escherichia coli strain K-12 sub-strain MG1655 (GenBank NC_000913.3) consisting of 319 bp were cloned into the dsRNA production vector pL4440 using Sac1 and Sma1 restriction sites for directional cloning. The program 'Primer3' [47] was used to design the oligonucleotides for amplification of gene-specific double stranded RNA (dsRNA): SsGST-mu1 forward primer 5'-TAT GAG CTC ATA TGC TGG CGT GGA TTT CG-3', SsGST-mu1 reverse primer 5'-TAT CCC 
GGG CAT CAG GAA GCT TAG CAA CCA-3', LacZ forward primer $5^{\prime}$-TAT GAG CTC CGT TAC CCA ACT TAA TCG CC-3', LacZ reverse primer 5'-TAT CCC GGG TGT GAG CGA GTA ACA ACC C-3'. Plasmids were linearised with the restriction enzyme $\mathrm{Sac1}$ (NEB, Ipswich, USA) and subsequently treated with Klenow enzyme (NEB) to remove the overhangs. dsRNA was synthesised using T7 RiboMAX ${ }^{\mathrm{mi}}$ Express RNAi system (Promega, Madison, USA) according to the manufacturer's instructions. dsRNA was quantified by ND1000 Nano-drop spectrophotometer (Thermo Fischer Scientific, Waltham, USA) and the quality was assessed by agarose gel electrophoresis. The dsRNA was diluted in normal saline (Sigma-Aldrich, St. Louis, USA) to a final concentration of $2.5 \mu \mathrm{g} / \mu \mathrm{l}$.

\section{Fluorescence labelling of dsRNA and assessment of uptake by S. scabiei}

SsGST-mu1 dsRNA was labelled using the Silencer ${ }^{\mathrm{ma}}$ siRNA labelling kit (Thermo Fischer Scientific). Ten $\mu$ labelling dye $\left(\mathrm{Cy}^{\circ}\right), 12.5 \mu \mathrm{g}$ SsGST-mu1 dsRNA in $15 \mu \mathrm{l}$

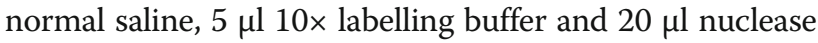
free water (Invitrogen, Carlsbad, USA) were combined and incubated at $37^{\circ} \mathrm{C}$ for $3 \mathrm{~h}$. To precipitate the dsRNA $5 \mu \mathrm{l} 5 \mathrm{M} \mathrm{NaCl}$ and $125 \mu \mathrm{l}$ cold $100 \%$ ethanol were mixed with the reaction and incubated $30 \mathrm{~min}$ at $-20{ }^{\circ} \mathrm{C}$. The dsRNA was pelleted by centrifugation at $18,400 \times g$ for 20 min at $4{ }^{\circ} \mathrm{C}$, washed with $70 \%$ ethanol and centrifuged for $5 \mathrm{~min}$ at the room temperature, air - dried and resuspended in $10 \mu \mathrm{l}$ of nuclease free normal saline (Sigma-Aldrich). Successful labelling was indicated by pink staining of the pellet and confirmed by agarose gel electrophoresis.

\section{dsRNA administration to S. scabiei}

Ten adult female mites were completely immersed in $10 \mu \mathrm{l}(1.25 \mu \mathrm{g} / \mu \mathrm{l})$ of fluorescently labelled dsRNA or unlabelled dsRNA on a detached cap of snaplock microcentrifuge tube (Axygen, Corning, USA) and incubated at $4{ }^{\circ} \mathrm{C}$ for $24 \mathrm{~h}$. Mites were washed 3 times with molecular grade water (Invitrogen) and immobilised for imaging on a benzyl benzoate coated Petri dish. Z stack images (30-60 slices) of mites that had ingested $\mathrm{Cy} 3^{\circ}$ labelled dsRNA were captured using a Zeiss 780-NLO confocal microscope with a 20x Plan-Apochromat (NA 0.8) lens. $\mathrm{Cy} 3^{\circ}$ was excited using a $561 \mathrm{~nm}$ laser attenuated $97 \%$ and emitted light (562 $\mathrm{nm}$ to $642 \mathrm{~nm}$ ) was captured using a GaAsP array detector. Images are presented as a single representative slice from each mite processed using Zen software (Carl Zeiss AG, Oberkochen, Germany).

\section{RNA extraction and quantification}

A series of 8 experiments was conducted to establish the optimal conditions for RNA interference (RNAi) in $S$. scabiei var. suis (Table 2). Every experiment involved 5 biological replicates. For each replicate 60 adult female mites were isolated from a scabetic skin crust within $3 \mathrm{~h}$ of removal from the host, randomly divided into 2 groups of 30 mites and completely immersed either in $20 \mu \mathrm{l}(2.5 \mu \mathrm{g} / \mu \mathrm{l})$ of SsGST-mu1 (test group) or LacZ dsRNA (control group). In total 2400 individual mites (30 mites per replicate, 5 replicates per treatment group, 2 treatment groups, 8 different conditions) were tested. The incubation conditions and durations of each experiment are further summarised in Table 2 .

Mites were examined periodically for signs of viability and dead mites and eggs that had been laid during incubation were removed from the solution. Following incubation, living mites were washed 3 times with molecular grade water (Invitrogen) and homogenised in a ZR BashingBead $^{\text {tw }}$ lysis tube containing $800 \mu \mathrm{l}$ RNA Lysis buffer (Zymo Research, Irvine, USA) using a Precellys ${ }^{\circ}$ homogeniser (Bertin, Montigny le Bretonneux, France) with 3 cycles of $3400 \times g$ for $23 \mathrm{~s}$ including $60 \mathrm{~s}$ interval in between cycles at $4{ }^{\circ} \mathrm{C}$. Lysates were centrifuged at

Table 2 Exposure of S. scabiei mites to dsRNA under different experimental conditions

\begin{tabular}{|c|c|c|c|c|c|}
\hline \multirow[t]{2}{*}{ Experiment } & \multicolumn{4}{|l|}{ Incubation } & \multirow[t]{2}{*}{ Survival rate (\%) } \\
\hline & dsRNA & $75 \%$ serum & Normal saline & Out of liquid $^{a}$ & \\
\hline 1 & $24 \mathrm{~h}, 4^{\circ} \mathrm{C}$ & na & na & na & 100 \\
\hline 2 & $48 \mathrm{~h}, 4^{\circ} \mathrm{C}$ & na & na & na & 100 \\
\hline 3 & $72 \mathrm{~h}, 4^{\circ} \mathrm{C}$ & na & na & na & 100 \\
\hline 4 & $24 \mathrm{~h}, 4^{\circ} \mathrm{C}$ & 24 h, RT & na & na & 93 \\
\hline 5 & $24 \mathrm{~h}, 4^{\circ} \mathrm{C}$ & $48 \mathrm{~h}, \mathrm{RT}^{\mathrm{b}}$ & na & na & 100 \\
\hline 6 & $24 \mathrm{~h}, 4^{\circ} \mathrm{C}$ & na & $24 \mathrm{~h}, \mathrm{RT}$ & na & 100 \\
\hline 7 & $24 \mathrm{~h}, 4^{\circ} \mathrm{C}$ & $24 \mathrm{~h}, \mathrm{RT}$ & $24 \mathrm{~h}, \mathrm{RT}$ & na & 100 \\
\hline 8 & $24 \mathrm{~h}, 4^{\circ} \mathrm{C}$ & na & na & $48 \mathrm{~h}, \mathrm{RT}^{\mathrm{a}}$ & 26 \\
\hline
\end{tabular}

Abbreviations: na, not applicable; RT, room temperature

${ }^{a}$ dsRNA was removed and mites were kept in humidifier chamber

${ }^{\mathrm{b}}$ Heat-inactivated serum was replaced after first $24 \mathrm{~h}$ 
$12,000 \times g$ for $1 \mathrm{~min}$ and the supernatant was transferred to a Zymo-Spin ${ }^{\text {Tax }}$ IIIC column (Zymo Research). Subsequently, RNA was extracted using the ZR Tissue and Insect RNA MicroPrep ${ }^{\mathrm{Tx}}$ kit (Zymo Research), including an on-column DNase I treatment step (following the manufacturer's instructions). RNA was quantified using a Qubit $^{\circ}$ RNA HS Assay kit (Thermo Fischer Scientific) with the Qubit ${ }^{\circ}$ Fluorometer (Thermo Fischer Scientific). Quality of the extracted RNA was assessed using a Qsep100 system with Q-Analyzer ${ }^{\mathrm{rm}}$ software (BiOptic, La Canada Flintridge, USA).

\section{Quantitative reverse transcription PCR (RT-qPCR)}

For the qPCR assessment of gene silencing at the transcriptional level following immersion of mites in dsRNA gene specific primers were designed using Primer3 [47]. To amplify a gene specific fragment of $198 \mathrm{bp}$ of the $S$. scabiei glutathione $\mathrm{S}$-transferase mu-class 1 gene the SsGST-mu1 qPCR forward primer 5'-TGG CCC GAA TCT GTT ACG AT-3' and the SsGST-mu1 qPCR reverse primer $5^{\prime}$-TGG TGA AAA TTT CTG GTG CAA A-3' were used. To amplify a $181 \mathrm{bp}$ fragment of the $S$. scabiei Elongation Factor 1 alpha gene the SsEF1 $\alpha$ qPCR forward primer 5'-TTG GCT TAT ACC TTG GGT GTG-3' and the SsEF1 $\alpha$ qPCR reverse primer 5'-CAC CGT TCC ATC CAG AGA TT-3' were used [48].

cDNA was synthesised from $250 \mathrm{ng}$ of total RNA using Superscript ${ }^{\circ}$ II reverse transcriptase (Thermo Fischer Scientific) and Oligo $(\mathrm{dT})_{20}$ primer (Thermo Fischer Scientific). Gene transcription was quantified using the CFX384 Touch $^{\text {Tux }}$ Real-Time PCR detection system (Bio-Rad, Hercules, USA) in triplicate reactions per biological replicate of each treatment group. qPCR was performed in $10 \mu \mathrm{l}$ reactions, consisting of $5 \mu \mathrm{l}$ LightCycler 480 SYBR Green I Mater (Roche, Dee Why, Australia), $1 \mu \mathrm{l}$ cDNA, $0.1 \mu \mathrm{l}$ each primer $(50 \mu \mathrm{M})$ and $3.8 \mu \mathrm{l}$ molecular grade water (Invitrogen). qPCR cycling times were $95{ }^{\circ} \mathrm{C}$ for $10 \mathrm{~min}$ followed by 45 cycles of $95{ }^{\circ} \mathrm{C}$ for $10 \mathrm{~s}, 50{ }^{\circ} \mathrm{C}$ for $10 \mathrm{~s}$ and $72{ }^{\circ} \mathrm{C}$ for $10 \mathrm{~s}$. Melt curve analysis was performed with the following cycle conditions: $95^{\circ} \mathrm{C}$ for $5 \mathrm{~s}, 65^{\circ} \mathrm{C}$ for $5 \mathrm{~s}$ and $95^{\circ} \mathrm{C}$ for $5 \mathrm{~s}$. qPCR standard curves with $90-110 \%$ reaction efficiency were consistently achieved using $10^{9}$ copies $/ \mu \mathrm{l}$ plasmid template DNA within the range of $10^{2}-10^{9}$ copies/ $\mu$ l. Average target gene transcription was normalised to the average transcription of the constitutively expressed reference housekeeping gene S. scabiei Elongation Factor 1 alpha $(S s E F 1 \alpha)[48]$.

Statistical differences in the mean transcription of the target gene between treatment group and control group was calculated with Student's $t$-test ( $P$-value of $<0.05$ considered significant), using GraphPad Prism 7 (GraphPad Software Inc., USA).

\section{Results}

Identification of genes involved in eukaryotic small RNAmediated silencing in Sarcoptes scabiei mite genomic databases

BLAST analyses were performed on the S. scabiei var. canis genome database [28], on three S. scabiei var. suis genome databases [26] and two S. scabiei var. hominis genome databases [26]. Each database contained over 10,000 annotated gene features and the CEGMA estimated completeness ranged from 93 to $99 \%$. For each BLAST result the best hit was selected. Domain predictions were obtained using NCBI domain prediction tools. The results are listed in Table 3 and respective gene and scaffold IDs are provided in Additional file 1: Table S1. No matches were obtained for Piwi, C3PO and the Dicer-2 cofactor R2D2.

\section{Uptake of fluorescently labelled dsRNA by S. scabiei Var. suis}

We successfully established a suitable method to introduce dsRNA into $S$. scabiei, adapted from a previously published protocol to silence genes in house dust mites [37]. After $24 \mathrm{~h}$ incubation of mites at $4{ }^{\circ} \mathrm{C}$ with fluorescently labelled SsGST-mu1 dsRNA at $1.25 \mu \mathrm{g} / \mu \mathrm{l}$, fluorescence was clearly visible in the mite gut (Fig. 1a), indicating oral uptake. Control group mites incubated with either unlabelled SsGST-mu1 dsRNA (Fig. 1b) did not exhibit fluorescence in their gut. This demonstrated that dsRNA can readily be delivered into the S. scabiei through non-invasive immersion. Mites in both groups exhibited auto-fluorescence across their body surface, due to the presence of the auto-fluorescent compounds pteridines and resilin in their cuticle; a feature commonly observed in arthropods when the cuticle is exposed to UV light [49].

\section{Efficiency and duration of gene knockdown in S. scabiei}

SsGST-mu1 gene transcription in mites that had been treated with SsGST-mu1 dsRNA (test group) was significantly $(P<0.05)$ reduced by about $35 \%$, in comparison to the LacZ dsRNA-treated control group (Fig. 2), when mites were incubated in dsRNA at $4{ }^{\circ} \mathrm{C}$ for $24 \mathrm{~h}$, followed by incubation with $75 \%$ heat inactivated serum for another $24 \mathrm{~h}(t=4.509, P=0.0020)$ (experiment 4, Fig. 2a) or $48 \mathrm{~h}(t=3.45, P=0.0110)$ (experiment 5, Fig. 2b). Repeats of these experiments confirmed the reproducibility of the above key finding. Direct and continuous serum incubation post exposure to RNA seemed essential for gene silencing to occur, as no significant reduction in the SsGST-mu1 gene transcription was observed if the mites were solely incubated in dsRNA (experiments 1-3), when dsRNA incubation was followed by $24 \mathrm{~h}$ normal saline incubation (experiment 6) or when dsRNA 
Table 3 S. scabiei genes involved in RNA interference

\begin{tabular}{|c|c|c|c|c|}
\hline \multirow[t]{2}{*}{ RNAi pathway gene } & \multirow[t]{2}{*}{ Protein function } & \multicolumn{3}{|l|}{ Databases } \\
\hline & & $\begin{array}{l}\text { S. scabiei } \\
\text { var. hominis }\end{array}$ & $\begin{array}{l}\text { S. scabiei } \\
\text { var. suis }\end{array}$ & $\begin{array}{l}\text { S. scabiei } \\
\text { var. canis }\end{array}$ \\
\hline Exportin & Nuclear export of shRNA and pre-miRNAs. [72] & + & + & + \\
\hline Drosha & $\begin{array}{l}\text { A nuclear RNase III that cleaves primary miRNAs (pri-miRNAs) to release hairpin-shaped } \\
\text { pre-miRNAs. These are subsequently cut by the cytoplasmic RNase III Dicer to generate } \\
\text { mature miRNAs. [73-75] }\end{array}$ & + & + & + \\
\hline Dicer & $\begin{array}{l}\text { Cleaves dsRNA and pre-miRNA into siRNA and miRNA, respectively. Facilitates the } \\
\text { activation of RISC. [50] }\end{array}$ & + & + & + \\
\hline Pasha & $\begin{array}{l}\text { Essential cofactor for Drosha playing a central role in binding single-stranded fragments } \\
\text { of the pri-mRNA. [74] }\end{array}$ & + & + & $t^{\mathrm{a}}$ \\
\hline Loquacious & $\begin{array}{l}\text { Cofactor of dicer that is important for enabling the incorporation of dsRNA in silencing } \\
\text { complexes. It mediates miRNA biogenesis and, thereby, the expression of genes regulated } \\
\text { by miRNAs. [76] }\end{array}$ & + & + & + \\
\hline Argonaute & $\begin{array}{l}\text { Argonaute proteins bind to different classes of small non-cording RNAs (miRNA, siRNA } \\
\text { and piRNAs) which leads to mRNA cleavage and subsequent silencing. [77] }\end{array}$ & + & + & + \\
\hline$R d R P$ & $\begin{array}{l}\text { RNA-dependent RNA polymerase that amplifies miRNAs and small temporal RNAs to } \\
\text { produce dsRNA which are then cleaved by the enzyme Dicer to produce siRNAs targeting } \\
\text { mRNAs for silencing. [78] }\end{array}$ & + & + & - \\
\hline VIG & Argonaute related protein in RISC that has role in RNA binding and nuclease activity. [79] & + & + & - \\
\hline GW182 & $\begin{array}{l}\text { Promotes target silencing by repressing translation and enhancing mRNA turnover, precise } \\
\text { mechanism of action unknown. [80] }\end{array}$ & - & $+^{\mathrm{a}}$ & - \\
\hline Piwi & Piwi proteins or piwi domains hydrolyse ssRNA. [81] & - & - & - \\
\hline CЗPO & Endoribonuclease that activates the RISC. [82] & - & - & - \\
\hline R2D2 & Co factor of dicer2 directing strand specific incorporation of the siRNA. $[53,83]$ & - & - & - \\
\hline
\end{tabular}

Key: + , denotes genes that were identified in the respective $S$. scabiei database; -, denotes genes that were not detected in the respective $S$. scabiei database ancomplete gene sequence was identified

incubation was followed by $24 \mathrm{~h}$ serum incubation and subsequent $24 \mathrm{~h}$ of normal saline incubation (experiment 7). Mite survival data under the different experimental conditions are provided in Table 2. Generally, mites were found alive after immersion in liquid over the maximum tested period of $72 \mathrm{~h}$, but irrespective of provided humidity, mites died if not kept in liquid (experiment 8). Notably, under the conditions of experiments 1-7 egg production seemed to be unaffected, as freshly laid mite eggs were observed.

\section{Discussion}

\section{Establishing RNAi in S. scabiei}

RNAi has become a widely used tool to knock down and analyse the function of genes, especially in organisms where in vitro culture systems are absent and the systematic generation of mutants is not feasible. RNAi is therefore a highly attractive experimental approach to test potential drug and vaccine targets in the scabies mite in vitro and in a relatively short time frame, as dictated by the short ex vivo live span of the mite.

Eukaryotic small RNA-mediated silencing involves three essential sets of molecules: small RNAs, Dicer enzymes and Argonaute proteins. Within the nucleus, MicroRNA genes are transcribed into primary microRNAs (pri-miRNAs) and processed by Drosha to release hairpin-shaped
pre-miRNAs which are exported by an exportin to the cytoplasm. The ribonuclease III enzyme Dicer excises the small RNAs from their precursors, thereby initiating the RNAi pathway by generating the active short interfering RNA (siRNA). dsRNA binding domain proteins (dsRBD) Pasha, Loquacious, and R2D2 are cofactors for processing events. Silencing is then effected by the RNA-induced silencing complex (RISC) and its RNaseH core enzyme Argonaute. The siRNA is unwound during RISC assembly. When a matching mRNA assembles with the siRNA nucleolytic degradation of the targeted mRNA by the RNaseH enzyme Argonaute occurs causing translational gene silencing $[41,50]$.

We have assembled here substantial genomic evidence of a complete RNAi machinery present in the S. scabiei. Notably, the genes for Piwi, C3PO and the R2D2 were not detected, which does not necessarily imply that the gene is absent in the $S$. scabiei, as the S. scabiei databases are not complete and annotations are still underway. Piwi for example has been found in the genomes of P. ovis [30] and T. urticae [42] and may indeed be found once $S$. scabiei genome analysis has further progressed.

Our demonstration of experimental gene silencing by means of RNAi manifests the presence of a classical functional gene silencing pathway triggered by dsRNA. Experimental delivery of dsRNA can present a challenge. 

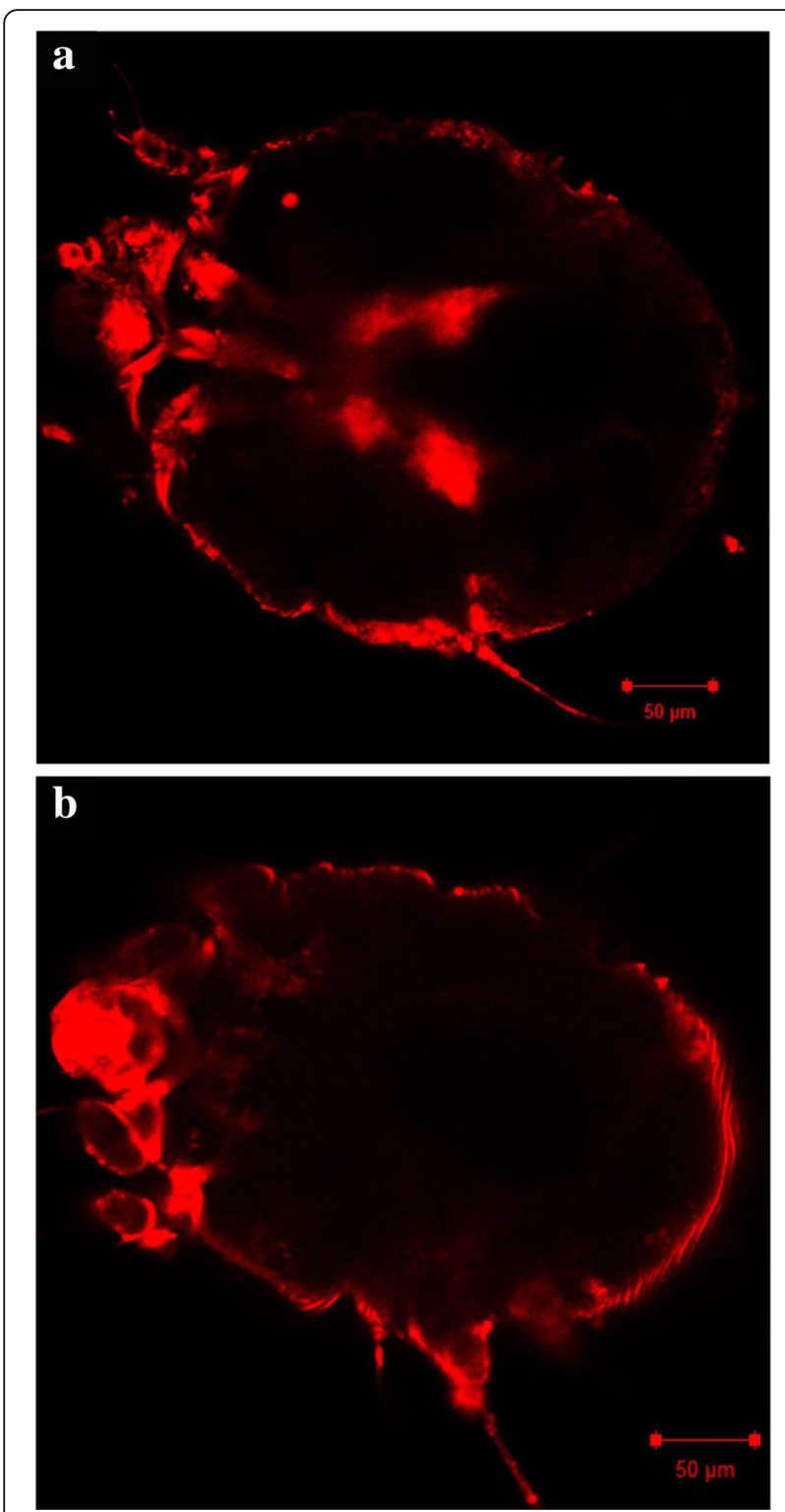

Fig. 1 Fluorescence-labelled dsRNA uptake in Sarcoptes scabiei var. suis. Mites were immersed for $24 \mathrm{~h}$ at $4^{\circ} \mathrm{C}$ in (a) Cy ${ }^{\oplus}$-labelled SsGSTmu1 dsRNA or (b) Unlabelled SsGST-mu1 dsRNA, and subsequently visualised by confocal microscopy at 20x magnification and excitation wavelength $561 \mathrm{~nm}$. Scale-bars: $50 \mu \mathrm{m}$

Injecting dsRNA directly into eggs, embryos or adult stages has been efficient in insects and ticks (reviewed in [30]) but is not easily achieved in small mites. Virusmediated methods have been trialled as another way to overexpress dsRNA [51]. In some but not all mites dsRNA can be introduced simply and efficiently by feeding [52] which allows the dsRNA to enter cells and induce a systemic RNAi effect. Non-invasive immersion has been demonstrated to be the simplest and most gentle experimental method in the honey bee mite, $V$. destructor [33] and the house dust mite, D. pteronyssinus
[37]. These mites have an experimental advantage as they are either truly ectoparasitic or free-living, respectively, whereas S. scabiei are obligatory living within host tissue and cannot be maintained in culture. Nevertheless in our experiments the mites survived and laid eggs while up to $78 \mathrm{~h}$ off the host. This indicates a significant achievement of physiological conditions that will in future studies facilitate the experimental assessment of drug targets in S. scabiei. Ingestion of labelled dsRNA, as demonstrated here, is a good indicator that we can successfully target genes in the S. scabiei gut.

GST enzymes in insects function in detoxification of insecticides [53]. Increased activity of delta and epsilon class GSTs is linked to resistance to organophosphates, DDT and pyrethroids (reviewed in [54]). GSTs have also been associated with macrocyclic lactone resistance in $T$. urticae [40, 55] and S. scabiei [39]. We chose SsGSTmu1 as the first target to trial gene silencing in S. scabiei because this is one of the few $S$. scabiei genes that have been studied at the transcriptional level [39] and GSTs have been the target of choice in previously successful trials of RNAi in other mite species [33, 37]. GSTs are housekeeping genes and have been found to be equally and constitutively expressed in synganglion, malpighian tubules and in the gut of the honey bee mite [33]. Sarcoptes scabiei possess at least six glutathione Stransferase genes (group 8 allergen candidates) [28, 56]. Three of these cluster with mu class GSTs, and the remaining are more related to the delta/epsilon classes of insects, which are of particular interest in the assessment of drug resistance [56]. By carefully selecting targeted regions within non-conserved regions of the gene, it was possible to differentiate between the S. scabiei GSTs, thereby preventing off-target effects. We chose the gut-localised S. scabiei GST-mu1 [57, 58], because the gut is easily accessible and also the most dominant compartment of the mite body. RNAi of GST genes should occur in the gut even in the absence of a systemic RNAi machinery. However, SsGST has been recently shown to increase in expression after removal of the parasite from the host (Kate Mounsey, personal communication). In this respect the $35 \%$ reduction of GST transmission we measured in experiments 4 and 5 indicates a strong RNAi effect. The silencing of other gene targets under these conditions may be even more profound.

The incubation with serum post dsRNA exposure seems to be crucial. Serum was heat-inactivated to remove nucleases and also to denature the antibodies and complement factors. The addition of serum may have provided a more conducive environment for the mites, mimicking conditions within the host epidermis ( $\mathrm{pH}$, ionic strength) ideal to perform physiological functions. In addition, the serum may also have provided a food source for the mites. 


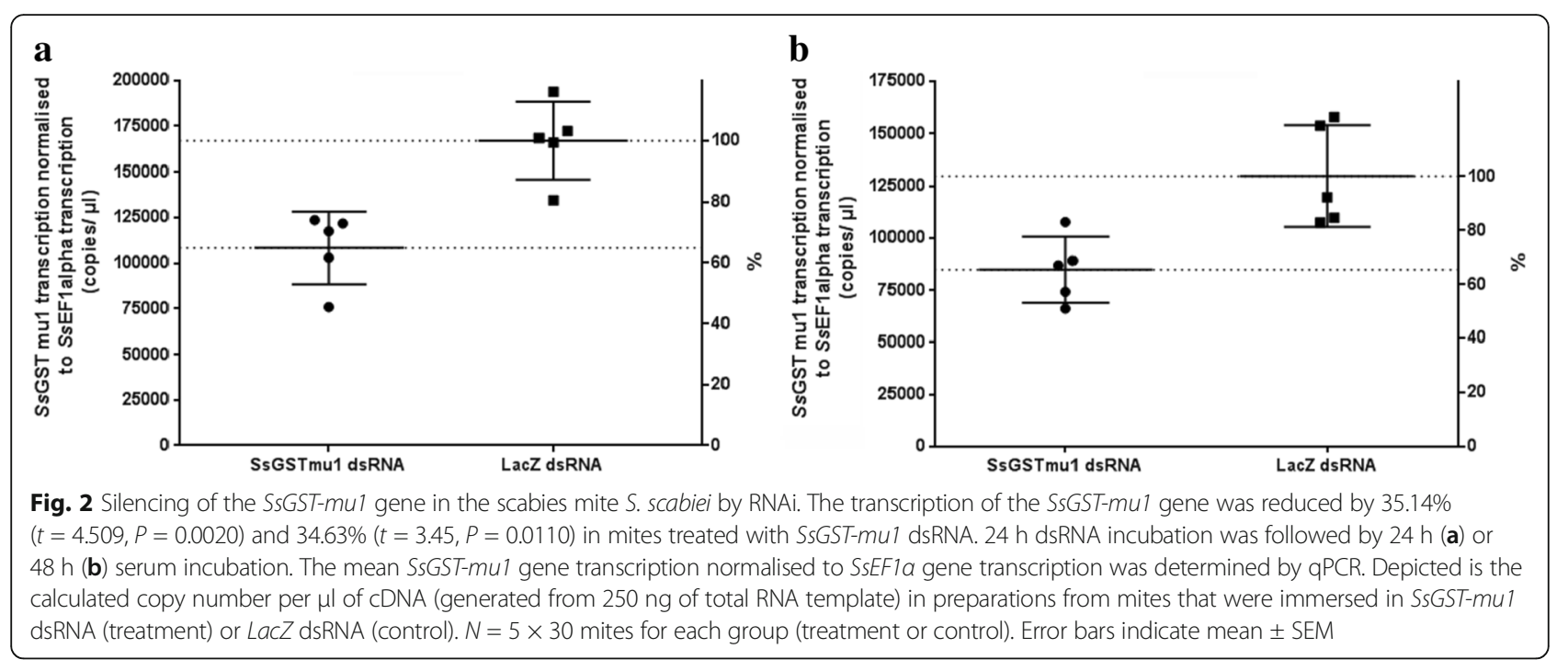

In the predatory mite $M$. occidentalis, RNAi could only be demonstrated after feeding mites on their hosts $T$. urticae [36]. Similarly it could be that S. scabiei also need food in order to successfully initiate the RNAi mechanism.

\section{Future directions}

This demonstration of RNAi in S. scabiei is well-timed with the recent publications of the complete mitochondrial genome [59] and nuclear draft genomes [26, 28] of this parasite. In addition transcriptome and microbiome data are underway, altogether providing an abundance of new information that might enable high throughput genome-wide RNAi studies. An interesting focus point is parasite-encoded proteases. Many of these are essential for regulating interactions between parasites and their hosts and, thus, are attractive anti-parasitic drug and/or vaccine targets. Burrowing scabies mites feed in the epidermis [60] and ingest a multitude of diverse host proteins. The feeding success of scabies mites depends on their ability to digest epidermal and plasma components and locally suppress the host complement and coagulation systems by releasing pharmacologically active proteins [61]. We have accumulated extensive data showing that $S$. scabiei express excretory gut proteins involved in these roles $[25,62]$, including families of active mite cysteine proteases [63], an active serine protease [64], proteolytically inactive serine protease paralogs with novel host complement-inhibitory functions [65-67] and protease inhibitors [68]. Following the optimisation on SsGST-mu1 and LacZ-dsRNA as control, we aim to apply RNAi to silence single genes of potential drug targets, i.e. SsSar s 3 [64] and SsAP [69]. Validation of the gene knockdown in mites could be performed by the established quantitative real-time PCR methods and at the protein level by previously established enzymatic assays and by immunohistology, using established antisera
$[64,70]$. Using the established porcine scabies model [27] it may also be possible to monitor phenotypic effects and mite survival in situ in the crusted pig skin lesion. As double stranded RNA proved here to be stable over days it might be worthwhile to trial topical treatment [71] with double stranded RNA targeting a gene essential for mite survival, with the aim to reduce mite numbers in an acute infection.

\section{Conclusion}

This demonstration of a significant reduction in the transcription of the Ss GST-mu1 gene represents the first published account of RNAi in S. scabiei and breaks the ground for future RNAi studies in this parasite. Scabies is of considerable medical relevance in particular with regards to complications due to mite associated secondary infections. With current chemotherapeutic control being not enough, the present RNAi approach has the potential to facilitate future research towards developing novel intervention methods.

\section{Additional file}

Additional file 1: Table S1. Gene IDs and scaffold IDs of S. scabiei genes involved in RNAi. (DOCX 20 kb)

\section{Abbreviations \\ dsRNA: Double stranded ribonucleic acid; qPCR: Quantitative polymerase chain reaction; RNAi: Ribonucleic acid interference; SsGST-mu1: Sarcoptes scabiei glutathione S-transferase mu-class 1; SsEF1 a: Sarcoptes scabiei elongation factor 1 alpha}

\section{Acknowledgements}

We acknowledge Mr. A Kelly and Ms. M Dekkers, Managers at the Queensland Animal Science Precinct (QASP) and their team for assistance in animal management. We acknowledge Mr. T Nguyen for assistance in confocal imaging at ACRF Centre for Comprehensive Biomedical Imaging in QIMR Berghofer Medical Research Institute. 


\section{Funding}

This research was supported by funding from the Australian Government National Health and Medical Research Council (Project Grant ID 1067192). KF was supported by an Australian Research Council Future Fellowship (FT130101875). DDF was supported by an international PhD scholarship from the QIMR Berghofer MRI and an UQ international scholarship from the University of Queensland. The funders had no role in study design, data collection and analysis, decision to publish, or preparation of the manuscript.

\section{Availability of data and materials}

The human and pig mite datasets analysed during the current study are available in the in the GigaScience repository and raw data in NCBI under BioProject accession: PRJEB12428 [26]. The dog mite dataset is available in public NCBI databases under BioProject accession PRJNA268368 [28].

\section{Authors' contributions}

KF, STGB and EJM conceived the study. DDF, EJM and MZ produced the data. DDF, EJM and SR performed the analysis. KF and STGB provided advice about the analysis. DDF and KF wrote the manuscript. All authors read and approved the final manuscript.

\section{Competing interests}

The authors declare that they have no competing interests.

\section{Consent for publication}

Not applicable.

\section{Ethics approva}

Animal care and handling procedures used in this study followed the Animal Care and Protection Act, in compliance with the Australian code of practice for the care and use of animals for scientific purposes, outlined by the Australian National Health and Medical Research Council. The study was approved by the Queensland Animal Science Precinct (QASP), University of Queensland and the QIMR Berghofer Medical Research Institute Animal Ethics Committees (SA 2015/03/504, QIMR P630).

\section{Author details}

'QIMR Berghofer Medical Research Institute, Infectious Diseases Department, 300 Herston Road, Herston, Brisbane 4006, Australia. ${ }^{2}$ School of Veterinary Sciences, University of Queensland, Gatton, QLD 4343, Australia. ${ }^{3}$ Parasitology Division, Moredun Research Institute, Pentlands Science Park, Bush Loan, Edinburgh, Midlothian, Scotland EH26 OPZ, UK. ${ }^{4}$ Department of Veterinary Pathobiology, Faculty of Veterinary Medicine and Animal Science, University of Peradeniya, Peradeniya, Sri Lanka.

Received: 16 March 2017 Accepted: 1 June 2017 Published online: 10 June 2017

\section{References}

1. Engelman D, Kiang K, Chosidow O, McCarthy J, Fuller C, Lammie P, et al Toward the global control of human scabies: introducing the international alliance for the control of scabies. PLoS Negl Trop Dis. 2013;7(8):e2167.

2. Engelman D, Fuller LC, Solomon AW, McCarthy JS, Hay RJ, Lammie PJ, et al. Opportunities for integrated control of neglected tropical diseases that affect the skin. Trends Parasitol. 2016;32(11):843-54.

3. Romani L, Steer AC, Whitfeld MJ, Kaldor JM. Prevalence of scabies and impetigo worldwide: a systematic review. Lancet Infect Dis. 2015;15(8):960-7.

4. Hay RJ, Johns NE, Williams HC, Bolliger IW, Dellavalle RP, Margolis DJ, et al. The global burden of skin disease in 2010: an analysis of the prevalence and impact of skin conditions. J Invest Dermatol. 2014;134(6):1527-34.

5. Feldmeier $H$, Heukelbach J. Epidermal parasitic skin diseases: a neglected category of poverty-associated plagues. Bull World Health Organ. 2009; 87(2):152-9

6. Karimkhani C, Dellavalle RP, Coffeng LE, Flohr C, Hay RJ, Langan SM, et al. Global skin disease morbidity and mortality: an update from the global burden of disease study 2013. JAMA Dermatol. 2017;153(5):406-12.

7. Hay RJ. Pyoderma and scabies: a benign association? Curr Opin Infect Dis. 2003;16(2):69-70

8. Currie BJ, McCarthy JS. Permethrin and ivermectin for scabies. N Engl J Med. 2010;362(8):717-25.
9. Arlian LG, Runyan RA, Achar S, Estes SA. Survival and infectivity of Sarcoptes scabiei var. canis and var. hominis. J Am Acad Dermatol. 1984;11(2):210-5.

10. Arlian LG, Runyan RA, Vyszenski-Moher DL. Water balance and nutrient procurement of Sarcoptes scabiei var. canis (Acari: Sarcoptidae). J Med Entomol. 1988;25(1):64-8.

11. Arlian LG, Vyszenski-Moher DL, Pole MJ. Survival of adults and development stages of Sarcoptes scabiei var. canis when off the host. Exp Appl Acarol. 1989;6(3):181-7.

12. Mellanby K. The transmission of scabies. Br Med J. 1941;9(20):405-6.

13. Smith HJ. Transmission of Sarcoptes scabiei in swine by fomites. Can Vet J. 1986;27(6):252-4.

14. Arlian LG, Estes SA, Vyszenski-Moher DL. Prevalence of Sarcoptes scabiei in the homes and nursing homes of scabietic patients. J Am Acad Dermatol. 1988;19(5):806-11.

15. Liu X, Walton S, Mounsey K. Vaccine against scabies: necessity and possibility. Parasitology. 2014;141(6):725-32.

16. Chosidow O. Clinical practices. Scabies. N Engl J Med. 2006:354(16):1718-27.

17. Strong $M$, Johnstone $P$. Cochrane review: interventions for treating scabies. Cochrane Database Syst Rev. 2011;6(6):1790-862

18. Bernigaud C, Fang F, Fischer K, Lespine A, Aho LS, Dreau D, et al. Preclinical study of single-dose moxidectin, a new oral treatment for scabies: efficacy, safety, and pharmacokinetics compared to two-dose ivermectin in a porcine model. PLoS Negl Trop Dis. 2016;10(10):e0005030.

19. Mounsey KE, Bernigaud C, Chosidow O, McCarthy JS. Prospects for moxidectin as a new oral treatment for human scabies. PLoS Negl Trop Dis. 2016;10(3): e0004389.

20. Pasay C, Walton S, Fischer K, Holt D, McCarthy J. PCR-based assay to survey for knockdown resistance to pyrethroid acaricides in human scabies mites (Sarcoptes scabiei var. hominis). Am J Trop Med Hyg. 2006;74(4):649-57.

21. Currie BJ, Harumal P, McKinnon M, Walton SF. First documentation of in vivo and in vitro ivermectin resistance in Sarcoptes scabiei. Clin Infect Dis. 2004; 39(1):e8-12.

22. Mounsey KE, Holt DC, McCarthy JS, Currie BJ, Walton SF. Longitudinal evidence of increasing in vitro tolerance of scabies mites to ivermectin in scabiesendemic communities. Arch Dermatol. 2009;145(7):840-1.

23. Arlian LG, Vyszenski-Moher DL, Rapp CM, Hull BE. Production of IL-1 alpha and IL-1 beta by human skin equivalents parasitized by Sarcoptes scabiei. J Parasitol. 1996:82(5):719-23.

24. Hengge UR, Currie BJ, Jager G, Lupi O, Schwartz RA. Scabies: a ubiquitous neglected skin disease. Lancet Infect Dis. 2006:6(12):769-79.

25. Holt DC, Fischer K. Novel insights into an old disease: recent developments in scabies mite biology. Curr Opin Infect Dis. 2013;26(2):110-5.

26. Mofiz E, Holt DC, Seemann T, Currie BJ, Fischer K, Papenfuss AT. Genomic resources and draft assemblies of the human and porcine varieties of scabies mites, Sarcoptes scabiei var. hominis and var. suis. GigaScience. 2016;5(1):1-4.

27. Mounsey K, Ho MF, Kelly A, Willis C, Pasay C, Kemp DJ, et al. A tractable experimental model for study of human and animal scabies. PLoS Negl Trop Dis. 2010;4(7):e756

28. Rider SD, Morgan MS, Arlian LG. Draft genome of the scabies mite. Parasit Vectors. 2015;8:585.

29. Morgan MS, Arlian LG, Rider SD Jr, Grunwald WC Jr, Cool DR. A proteomic analysis of Sarcoptes scabiei (Acari: Sarcoptidae). J Med Entomol. 2016;53(3):553-61.

30. Marr EJ, Sargison ND, Nisbet AJ, Burgess STG. RNA interference for the identification of ectoparasite vaccine candidates. Parasite Immunol. 2014; 36(1):616-26.

31. Galay RL, Umemiya-Shirafuji R, Mochizuki M, Fujisaki K, Tanaka T. RNA interference - a powerful functional analysis tool for studying tick biology and its control. INTECH. 2016; doi:10.5772/61577.

32. Garbian Y, Maori E, Kalev H, Shafir S, Sela I. Bidirectional transfer of RNAi between honey bee and Varroa destructor: Varroa gene silencing reduces Varroa population. PLoS Pathog. 2012;8(12):e1003035.

33. Campbell EM, Budge GE, Bowman AS. Gene-knockdown in the honey bee mite Varroa destructor by a non-invasive approach: studies on a glutathione S-transferase. Parasit Vectors. 2010:3:73.

34. Khila A, Grbic M. Gene silencing in the spider mite Tetranychus urticae: dsRNA and siRNA parental silencing of the distal-less gene. Dev Genes Evol. 2007;217(3):241-51.

35. Kamau LM, Wright HW, Nisbet AJ, Bowman AS. Development of an RNAinterference procedure for gene knockdown in the poultry red mite, Dermanysus gallinae: studies on histamine releasing factor and Cathepsin-D. Afr J Biotechnol. 2013;12(12):1350-6. 
36. Wu K, Hoy MA. Oral delivery of double-stranded RNA induces prolonged and systemic gene knockdown in Metaseiulus occidentalis only after feeding on Tetranychus urticae. Exp Appl Acarol. 2014;63(2):171-87.

37. Marr EJ, Sargison ND, Nisbet AJ, Burgess ST. Gene silencing by RNA interference in the house dust mite, Dermatophagoides pteronyssinus. Mol Cell Probes. 2015; 29(6):522-6.

38. Molin EU, Mattsson JG. Effect of acaricides on the activity of glutathione transferases from the parasitic mite Sarcoptes scabiei. Parasitology. 2008;135(1):115-23.

39. Mounsey KE, Pasay CJ, Arlian LG, Morgan MS, Holt DC, Currie BJ, et al. Increased transcription of glutathione S-transferases in acaricide exposed scabies mites. Parasit Vectors. 2010;3:43.

40. Stumpf N, Nauen R. Biochemical markers linked to abamectin resistance in Tetranychus urticae (Acari: Tetranychidae). Pestic Biochem Physiol. 2002;72(2): 111-21.

41. Carthew RW, Sontheimer EJ. Origins and mechanisms of miRNAs and siRNAs. Cell. 2009;136(4):642-55.

42. Grbic M, Van Leeuwen T, Clark RM, Rombauts S, Rouze P, Grbic V, et al. The genome of Tetranychus urticae reveals herbivorous pest adaptations. Nature. 2011;479(7374):487-92.

43. Altschul SF, Gish W, Miller W, Myers EW, Lipman DJ. Basic local alignment search tool. J Mol Biol. 1990;215(3):403-10.

44. Kent WJ. BLAT - the BLAST-like alignment tool. Genome Res. 2002;12(4):656-64.

45. Campbell MS, Holt C, Moore B, Yandell M. Genome annotation and curation using MAKER and MAKER-P. Curr Protoc Bioinformatics. 2014;48(4):11.1-39.

46. Campbell MS, Law M, Holt C, Stein JC, Moghe GD, Hufnagel DE, et al. MAKER$\mathrm{P}$ : a tool kit for the rapid creation, management, and quality control of plant genome annotations. Plant Physiol. 2014;164(2):513-24.

47. Rozen S, Skaletsky H. Primer3 on the WWW for general users and for biologist programmers. Methods Mol Biol. 2000;132:365-86.

48. Mounsey KE, Willis C, Burgess STG, Holt DC, McCarthy J, Fischer K. Quantitative PCR-based genome size estimation of the astigmatid mites Sarcoptes scabiei, Psoroptes ovis and Dermatophagoides pteronyssinus. Parasit Vectors. 2012;5:3.

49. Valdecasas AG, Abad A. Morphological confocal microscopy in arthropods and the enhancement of autofluorescence after proteinase $\mathrm{K}$ extraction. Microsc Microanal. 2011;17(1):109-13.

50. Hammond SM. Dicing and slicing: the core machinery of the RNA interference pathway. FEBS Lett. 2005;579(26):5822-9.

51. Garcia S, Billecocg A, Crance JM, Prins M, Garin D, Bouloy M. Viral suppressors of RNA interference impair RNA silencing induced by a Semliki forest virus replicon in tick cells. J Gen Virol. 2006;87(7):1985-9.

52. Kwon DH, Park JH, Lee SH. Screening of lethal genes for feeding RNAi by leaf disc-mediated systematic delivery of dsRNA in Tetranychus urticae. Pestic Biochem Physiol. 2013;105(1):69-75

53. Sheehan D, Meade G, Foley VM, Dowd CA. Structure, function and evolution of glutathione transferases: implications for classification of non-mammalian members of an ancient enzyme superfamily. Biochem J. 2001;360(1):1-16.

54. Hemingway J, Hawkes NJ, McCarroll L, Ranson H. The molecular basis of insecticide resistance in mosquitoes. Insect Biochem Mol Biol. 2004;34(7):653-65.

55. Konanz S, Nauen N. Purification and partial characterization of a glutathione S-transferase from the two-spotted spider mite, Tetranychus urticae. Pestic Biochem Physiol. 2004;79(2):49-57.

56. Dougall A, Holt DC, Fischer K, Currie BJ, Kemp DJ, Walton SF. Identification and characterization of Sarcoptes scabiei and Dermatophagoides pteronyssinus glutathione S-transferases: implication as a potential major allergen in crusted scabies. Am J Trop Med Hyg. 2005;73(5):977-84.

57. Pettersson EU, Ljunggren EL, Morrison DA, Mattsson JG. Functional analysis and localisation of a delta-class glutathione S-transferase from Sarcoptes scabiei. Int J Parasitol. 2005;35(1):39-48.

58. Willis C, Fischer K, Walton SF, Currie BJ, Kemp DJ. Scabies mite inactivated serine protease paralogues are present both internally in the mite gut and externally in feces. Am J Trop Med Hyg. 2006;75(4):683-7.

59. Mofiz E, Seemann T, Bahlo M, Holt D, Currie BJ, Fischer $K$, et al. Mitochondrial genome sequence of the scabies mite provides insight into the genetic diversity of individual scabies infections. PLoS Negl Trop Dis. 2016;10(2):e0004384

60. Levi A, Mumcuoglu KY, Ingber A, Enk CD. Assessment of Sarcoptes scabiei viability in vivo by reflectance confocal microscopy. Lasers Med Sci. 2011;26(3):291-2.

61. Fischer K, Holt D, Currie B, Kemp D. Scabies: important clinical consequences explained by new molecular studies. Adv Parasitol. 2012;79:339-73.

62. Holt DC, Burgess ST, Reynolds SL, Mahmood W, Fischer K. Intestinal proteases of free-living and parasitic astigmatid mites. Cell Tissue Res. 2013;351(2):339-52.
63. Holt DC, Fischer K, Pizzutto SJ, Currie BJ, Walton SF, Kemp DJ. A multigene family of inactivated cysteine proteases in Sarcoptes scabiei. J Invest Dermatol. 2004;123(1):240-1.

64. Beckham SA, Boyd SE, Reynolds S, Willis C, Johnstone M, Mika A, et al. Characterization of a serine protease homologous to house dust mite group 3 allergens from the scabies mite Sarcoptes scabiei. J Biol Chem. 2009;284(49):34413-22

65. Holt DC, Fischer K, Allen GE, Wilson D, Wilson P, Slade R, et al. Mechanisms for a novel immune evasion strategy in the scabies mite Sarcoptes scabiei: a multigene family of inactivated serine proteases. J Invest Dermatol. 2003; 121(6):1419-24

66. Bergstrom FC, Reynolds S, Johnstone M, Pike RN, Buckle AM, Kemp DJ, et al. Scabies mite inactivated serine protease paralogs inhibit the human complement system. J Immunol. 2009;182(12):7809-17.

67. Fischer K, Langendorf CG, Irving JA, Reynolds S, Willis C, Beckham S, et al. Structural mechanisms of inactivation in scabies mite serine protease paralogues. J Mol Biol. 2009;390(4):635-45.

68. Mika A, Reynolds SL, Mohlin FC, Willis C, Swe PM, Pickering DA, et al. Novel scabies mite serpins inhibit the three pathways of the human complement system. PLoS One. 2012;7(7):e40489.

69. Mahmood W, Viberg LT, Fischer K, Walton SF, Holt DC. An aspartic protease of the scabies mite Sarcoptes scabiei is involved in the digestion of host skin and blood macromolecules. PLoS Negl Trop Dis. 2013;7(11):e2525.

70. Reynolds S, Fischer K. The role of proteolytically inactive serine proteases from Sarcoptes scabiei in complement evasion. In: Dunn BM, editor. Proteinases as drug targets. Cambridge: Royal Society of Chemistry Publishing; 2012. p. 96-117.

71. Pridgeon JW, Zhao L, Becnel JJ, Strickman DA, Clark GG, Linthicum KJ. Topically Applied AaelAP1 Double-Stranded RNA Kills Female Adults of Aedes aegypti. J Med Entomol. 2008;45(3):414-20

72. Yi R, Qin Y, Macara IG, Cullen BR. Exportin-5 mediates the nuclear export of pre-microRNAs and short hairpin RNAs. Genes Dev. 2003;17(24):3011-6.

73. Lee $\mathrm{Y}$, Han J, Yeom $\mathrm{KH}$, Jin $\mathrm{H}$, Kim VN. Drosha in primary microRNA processing. Cold Spring Harb Symp Quant Biol. 2006;71:51-7.

74. Yeom KH, Lee Y, Han J, Suh MR, Kim VN. Characterization of DGCR8/Pasha, the essential cofactor for Drosha in primary miRNA processing. Nucleic Acids Res. 2006;34(16):4622-9.

75. Han J, Lee Y, Yeom KH, Nam JW, Heo I, Rhee JK, et al. Molecular basis for the recognition of primary microRNAs by the Drosha-DGCR8 complex. Cell. 2006;125(5):887-901.

76. Saito K, Ishizuka A, Siomi H, Siomi MC. Processing of pre-microRNAs by the dicer-1-Loquacious complex in Drosophila cells. PLoS Biol. 2005;3(7):e235.

77. Ender C, Meister G. Argonaute proteins at a glance. J Cell Sci. 2010;123(11): 1819-23.

78. Birchler JA. Ubiquitous RNA-dependent RNA polymerase and gene silencing. Genome Biol. 2009;10(11):243.

79. Caudy AA, Myers M, Hannon GJ, Hammond SM. Fragile X-related protein and VIG associate with the RNA interference machinery. Genes Dev. 2002; 16(19):2491-6.

80. Braun $J E_{\text {, Huntzinger }}$, Izaurralde $E$. The role of $\mathrm{GW} 182$ proteins in miRNAmediated gene silencing. Adv Exp Med Biol. 2013;768:147-63.

81. Saito K, Nishida KM, Mori T, Kawamura Y, Miyoshi K, Nagami T, et al. Specific association of Piwi with rasiRNAs derived from retrotransposon and heterochromatic regions in the Drosophila genome. Genes Dev. 2006:20(16):2214-22.

82. Liu Y, Ye X, Jiang F, Liang C, Chen D, Peng J, et al. C3PO, an endoribonuclease that promotes RNAi by facilitating RISC activation. Science. 2009;325(5941):750-3.

83. Liu Q, Rand TA, Kalidas S, Du F, Kim HE, Smith DP, et al. R2D2, a bridge between the initiation and effector steps of the Drosophila RNAi pathway. Science. 2003:301(5641):1921-5. 